\title{
Hypophysectomy and hormonal therapy modulate mK1-immunoreactive duct cells in the mice sublingual glands
}

\author{
Shingo Kurabuchi · Edward W. Gresik • \\ Chenjuan Yao $\cdot$ Kazuo Hosoi
}

Received: 4 October 2007/ Accepted: 30 July 2008/Published online: 22 August 2008

(C) The Author(s) 2008. This article is published with open access at Springerlink.com

\begin{abstract}
The immunocytochemical localization of a true tissue kallikrein, mK1, in mouse sublingual glands (SLGs) was examined following hypophysectomy and hormonal replacement therapy. In the glands of intact mice (14 weeks of age), mK1 was detected in the striated ducts (SDs). Full-fledged granular cells were scattered in the SDs of male mice (but not in those of female mice), showing a cellular mosaic distribution of $\mathrm{mK} 1$ with some being positive and others being negative. $\mathrm{mK} 1$ was also detected in transitional-type granular cells, though the secretory granules were too small and scarce to be visible by a light microscopy. Hypophysectomy in male mice resulted in the atrophy and loss of secretory granules in many SD cells. Granulation recovered after the repeated injection of $5 \alpha$ dihydrotestosterone (DHT), 3,5,3'-triiodo-L thyronine $\left(\mathrm{T}_{3}\right.$ ), and dexamethasone (Dex), given either alone or in combination to the hypophysectomized mice. The concomitant injection of DHT and $\mathrm{T}_{3}$, with or without Dex, resulted in the reappearance of the full-fledged granular cells, only some of which were mK1-positive. Electron microscopy revealed $\mathrm{mK} 1$ to be present exclusively in the secretory granules of these mK1-positive cells, and no ultrastructural
\end{abstract}

\footnotetext{
S. Kurabuchi ( $\square)$

Department of Histology, The Nippon Dental University School of Life Dentistry, Tokyo 102-8159, Japan

e-mail: kurab-fm@tky.ndu.ac.jp

E. W. Gresik

Department of Cell Biology and Anatomical Sciences, City

University of New York Medical School, New York,

NY 10031, USA

C. Yao $\cdot$ K. Hosoi

Department of Molecular Oral Physiology, Institute of Health

Biosciences, The University of Tokushima Graduate School,

Tokushima 770-8504, Japan
}

differences were observed between mK1-positive and mK1negative full-fledged granular cells. These results show that the differentiation of the granular cell phenotype in the mouse SLG duct system requires the concomitant action of androgen and thyroid hormone and retards mK1 synthesis.

Keywords Mouse true/renal tissue kallikrein · Granular striated tubule $\cdot$ Sublingual gland . Hormonal regulation · Immunocytochemistry

\section{Introduction}

Mouse tissue (glandular) kallikreins constitute a large family of serine proteinases encoded by 25-30 genes (Mason et al. 1983; Evans et al. 1987); the proteinases were named $\mathrm{mK} 1-\mathrm{mK} 26$, their genes were named mK1k1mK1k26 (Berg et al. 1992). Submandibular gland (SMG) is known to contain $\mathrm{mK} 1, \mathrm{mK} 9, \mathrm{mK} 13$, and $\mathrm{mK} 26$, including epidermal growth factor (EGF), nerve growth factor (NGF), and renin (Barka 1980). mK9, mK13, and mK26 are identical to EGF-binding protein (Taylor et al. 1974), $\beta$ NGF-endopeptidase (Smith et al. 1968; Satch et al. 1976, 1980), and prorenin converting enzyme-2 (Kim et al. 1991), respectively. mK1 was identified as a true/renal tissue kallikrein (Hosoi et al. 1983, 1994), suggesting that this enzyme has the strongest kinin-releasing activity of both L- and H-kininogens, relative to other members of the mouse tissue kallikrein gene family. Thus, $\mathrm{mK} 1$, which is widely expressed in the digestive organs as well as glandular tissues, such as salivary glands and pancreas, is expected to play a key role in the kallikrein-kinin system (Ganong 1997).

In the SMGs of ICR-strain mice, mK1 synthesis is inhibited by androgen, unlike other members of the 
kallikrein gene family, growth factors, and renin (Hosoi et al. 1992), and the mK1 content is significantly lower in the glands of male mice than in those of female mice (Hosoi et al. 1983, 1984). Our previous immunocytochemical study, using an antibody specific to $\mathrm{mK} 1$, demonstrated that the lower mK1 content in the SMGs of male mice is due to a significantly smaller number of mK1positive granular convoluted tubule (GCT) cells (Kurabuchi et al. 1999). We confirmed that essentially all of the immature GCT cells in the glands of prepubertal mice stained positive for $\mathrm{mK} 1$, whereas after the onset of puberty, many of the cells differentiated into full-fledged granular cells and became negative for mK1 (Kurabuchi et al. 2001, 2002, 2004). We also confirmed that all the atrophied GCT cells following hypophysectomy were mK1-positive, whereas, many of the GCT cells that developed a granular cell phenotype after hormone replacement therapy (Kurabuchi 2002) became mK1-negative (Kurabuchi et al. 2004). Taken together, these findings suggest that $\mathrm{mK} 1$ is a marker of granular duct cells with a poor granular cell phenotype.

Paradoxically, however, the $\mathrm{mK} 1$ content in the three major salivary glands was not consistently higher in female mice than in male mice in several mouse strains, including ICR (Murai 1987), while in the SMGs of hypophysectomized $\mathrm{C} 3 \mathrm{H} / \mathrm{HeN}$-strain mice, androgen significantly up regulated mK1 synthesis (Kurihara et al. 1999). To the best of our knowledge, the immunocytochemistry of mK1 has not yet been examined, except in the SMGs of ICR-strain mice. We hypothesized that the percentage of mK1-positive cells and their granular cell phenotype are essential determinants of the mK1 content in the gland and these indexes would vary with age, sex, strain of mice, and kind of gland. Thus, the aim of the present study was to confirm the localization and distribution of $\mathrm{mK} 1$ in the sublingual glands (SLGs) of ICR-strain mice and to define the hormonal modulation of mK1-immunoreactive granular duct cells using hypophysectomized male mice and hormonal therapy.

\section{Materials and methods}

Animals and experimental procedures

All animal experiments were conducted in compliance with the Guidelines of the National Institutes of Health (NIH) and the Nippon Dental University for the Care and Use of Laboratory Animals. Intact male and female and hypophysectomized male ICR (CD-1)-strain mice were purchased from Japan SLC, Inc (Shizuoka, Japan). Hypophysectomy had been performed in the mice at 4 weeks of age via the external auditory canal under pentobarbital anesthesia. The animals were housed under controlled environmental conditions $\left(22^{\circ} \mathrm{C}, \mathrm{LD} 12 \mathrm{~h}: 12 \mathrm{~h}\right)$, and provided with food and water ad libitum. At 12 weeks of age, the hypophysectomized mice were divided into eight groups, each group consisting of at least five animals, and injected with hormones as described in our previous papers (Kurabuchi 2002, 2006; Kurabuchi and Gresik 2001; Kurabuchi et al. 2002, 2004). In brief, the doses (per kg body weight) per injection of the hormones were as follows: $5 \alpha$-dihydrotestosterone (DHT: Wako Ltd., Osaka, Japan), $20 \mathrm{mg}$; dexamethasone (Dex: Wako Ltd., Osaka, Japan), $10 \mathrm{mg}$; 3,5,3'-triiodo-L thyronine ( $\mathrm{T}_{3}$ : ICN Biochem, Aurora, Ohio, USA), $1 \mathrm{mg}$. The two steroid hormones were dissolved in sesame oil (DHT, $6 \mathrm{mg} / \mathrm{ml}$ and Dex, $3 \mathrm{mg} / \mathrm{ml}$ ) and $\mathrm{T}_{3}$ was prepared immediately before use (at $0.3 \mathrm{mg} / \mathrm{ml}$ in $0.005 \mathrm{~N}$ $\mathrm{NaOH}$ in $0.9 \% \mathrm{NaCl}$ ). Three out of the eight groups of hypophysectomized mice were treated with any one of the above hormones, while three others were treated with any two of the three hormones, and one, was administered all the three hormones; the remaining one group of hypophysectomized mice not administered any hormone injection and the intact male and female mice matched for age were used as controls. After the final injection of the hormones, all the hormone-injected as well as the control animals, grown up to 14 weeks of age, were deprived of food/water overnight and sacrificed. Under anesthesia with Nembutal (30 $\mathrm{mg} / \mathrm{kg}$ body weight, intraperitoneal injection), the animals were sacrificed by exsanguination, and then, a fixative solution (a mixture of cold $2 \%$ glutaraldehyde and $2 \%$ paraformaldehyde in $0.05 \mathrm{M}$ cacodylate buffer, $\mathrm{pH}$ 7.4) was perfused through the vasculature. The SLGs were removed, minced and immersed in the same fixative solution for $5 \mathrm{~h}$ at $4^{\circ} \mathrm{C}$. After dehydration by passage through a graded series of ethanol, the tissues were embedded in Epon/Araldite.

\section{Immunocytochemistry}

$2-\mu \mathrm{m}$-thick sections were mounted on silane-coated slides (Matsunami Co., Tokyo, Japan) for light microscopy. After removal of the resin, the sections were incubated for $30 \mathrm{~min}$ in $0.3 \% \mathrm{H}_{2} \mathrm{O}_{2}$ in methanol to inhibit the endogenous peroxidase activity. The sections were then washed in distilled water (DW) and phosphate-buffered saline (PBS: $0.14 \mathrm{M} \mathrm{NaCl}$ in $0.01 \mathrm{M}$ sodium phosphate buffer and $0.14 \mathrm{M} \mathrm{NaCl}, \mathrm{pH}$ 7.5), and immunostained by the avidinbiotin peroxidase complex method, according to the manufacturer's protocol (Vectastain Elite ABC kit, Vector Labs, Burlingame, CA). They were then incubated overnight at room temperature with anti-mK1 antiserum (Kurabuchi et al. 1999), diluted 1:40,000, as the primary antibody. Thereafter, peroxidase activity was detected by incubation for $3-5 \mathrm{~min}$ in $1 \% \quad 3,3^{\prime}$-diaminobenzidine 
tetrahydrochloride (Dojin Lab., Kumamoto, Japan), 0.01\% $\mathrm{H}_{2} \mathrm{O}_{2}, 0.05$ M Tris-HCl, pH 7.6. The sections were then dehydrated with ethanol, mounted in Entellan (Merck, Gibbstown, NJ) and examined under a BX-50 microscope and by the Nomarski differential interference contrast optics method (Olympus, Tokyo).

For electron microscopy, ultrathin sections on gold grids were etched with $3 \% \mathrm{H}_{2} \mathrm{O}_{2}$ for $5 \mathrm{~min}$, thoroughly rinsed with DW, and subjected to immunostaining for $\mathrm{mK} 1$ using the protein A-gold technique. They were first incubated with 20\% NGS for $2 \mathrm{~h}$, directly transferred into a drop of antiserum specific for $\mathrm{mK} 1$ (1:40,000 diluted) and incubated overnight at $4^{\circ} \mathrm{C}$. Sections were rinsed three times in PBS and incubated with biotinylated goat anti-rabbit IgG (Vectastain Elite ABC kit) for $1 \mathrm{~h}$, followed by washing. Finally, they were incubated with a 1:100-dilution of streptavidin conjugated with 20 -nm gold particles (ICN Biochem, Aurora, Ohio, USA) for $1 \mathrm{~h}$. Sections were contrasted with uranyl acetate and lead citrate, and viewed under a transmission electron microscope (JEM-2000EXII, JEOL, Tokyo) at an acceleration voltage of $80 \mathrm{kV}$.

\section{Results}

Light-microscopic immunocytochemistry

\section{Intact male and female mice}

The intralobular duct system in the mouse SLGs of both sexes consisted of intercalated duct (ID), striated duct (SD) and excretory duct (ED). Specific immunostaining for $\mathrm{mK} 1$ was detected exclusively in a large portion of the SD segments. No immunostained cells were found in the segments of ID and ED. The granular duct cells were roughly classified into two cell types: the full-fledged granular cells, and the transitional-type cells (called as such by HazenMartin et al. 1987). The full-fledged granular cells contained numerous secretory granules, which were large enough to be visible under the light microscope, and a round nucleus at their base (Fig. 1a). They showed a mosaic cellular distribution of $\mathrm{mK} 1$, with some cells showing positive staining for $\mathrm{mK} 1$, and others negative staining for mK1 (Fig. 1a). This cell type could be clearly visualized in the SDs of the glands of male mice, but not in those of female mice (Fig. 1a, b). The latter type of cells, on the other hand, were represented by cells having a round nucleus in their apical one-third to half, and their apical rim being moderately immunostained for mK1 (Fig. 1b), although no secretory granules could be clearly distinguished in the immunostaining area under the light microscope. The Nomarsky differential-interference contrast microscopic images revealed the presence of a few non-granular cells, referred to as the pillar cells, or nongranular duct cells (data not shown). In the glands of the male mice, the granular duct cells, consisting of the transitional cells and the full-fledged granular cells, accounted for approximately $80 \%$ of the population of the striated duct cells. Approximately two-thirds of them were fullfledged cells, with the remaining being transitional cells (Fig. 2). While almost all of the transitional cells showed positive staining for $\mathrm{mK} 1$, approximately two-thirds of the full-fledged granular cells showed positive staining for $\mathrm{mK} 1$, the remaining being $\mathrm{mK} 1$-negative (mosaic cellular distribution of mK1) (Fig. 3). On the other hand, in the glands of the female mice, the granular duct cells accounted for approximately only $40 \%$ of the total population of the striated duct cells, this percentage being markedly lower than that in the glands of the male mice $(P<0.005$, Fig. 2$)$; most of the granular duct cells were the transitional-type cells, with full-fledged cells being rarely found, accounting for less than $1 \%$ of the entire population of the SD cells (Figs. 2, 3).

\section{Hypophysectomized male mice}

In the SLGs of the hypophysectomized male mice, a marked decrease in the intensity/extent of immunostaining for $\mathrm{mK} 1$ was observed in the SD segments with only a few transitional cells showing positive immunostaining at their apical rim (Fig. 1c). There were no full-fledged granular cells, either positively or negatively immunostained for $\mathrm{mK} 1$. The immunostained transitional cells in the glands of the hypophysectomized male mice accounted for less than $10 \%$ of the population of the striated duct cells, this percentage being markedly lower than that in the glands of the intact male and female mice $(P<0.0005$; Fig. 2$)$.

\section{Hormone-injected hypophysectomized male mice}

After injection of Dex alone, $\mathrm{T}_{3}$ alone or DHT alone on every alternate day for 2 weeks, marked restoration of $\mathrm{mK} 1$ immunostaining at the apical rim of the granular duct cells was observed in the SLGs of the hypophysectomized male mice (Fig. 1d-f). The immunostaining was a little stronger and more extensive in the glands of mice injected with $\mathrm{T}_{3}$ alone and DHT alone as compared with the glands of mice injected with Dex alone. However, no appearance of fullfledged granular cells was induced in the glands of any of these three groups. Nomarsky differential-interference contrast microscopy revealed that in all the three groups, almost all of the transitional cells in the glands showed positive staining for mK1 (Fig. 3). The transitional cells accounted for approximately $80 \%$ of the population of SD cells in each group. This percentage was close to the percentage of the total granular duct cells, composed of both transitional cells 
Fig. 1 Nomarski image of 2$\mu \mathrm{m}$-thick sections of SLGs of intact male and female mice (a, b), and hypophysectomized (Hypox) male mice (c-h); immunostaining with anti-mK1 antiserum. Both full-fledged granular cells and transitional cells are seen in the granular duct segments of the intact male mouse (a), whereas only the latter type cells are observed in those of the intact female mouse (b), indicating sexual dimorphism. Complete absence of the secretory granules was observed in many SD cells in the hypophysectomized animals, while a few $\mathrm{mK} 1$ positive cells (arrowhead) were left (c). After injection of Dex (d), $\mathrm{T}_{3}$ (e) and DHT (f), many mK1-positive transitional cells were restored in the SD segments. After injection of $\mathrm{DHT}+\mathrm{T}_{3}(\mathbf{g})$ and

DHT $+\mathrm{T}_{3}+$ Dex (h), fullfledged granular cells were induced in the SD segments. Arrows in a, g, and $\mathrm{h}$ show mK1-negative full-fledged granular cells. Bar $=40 \mu \mathrm{m}$
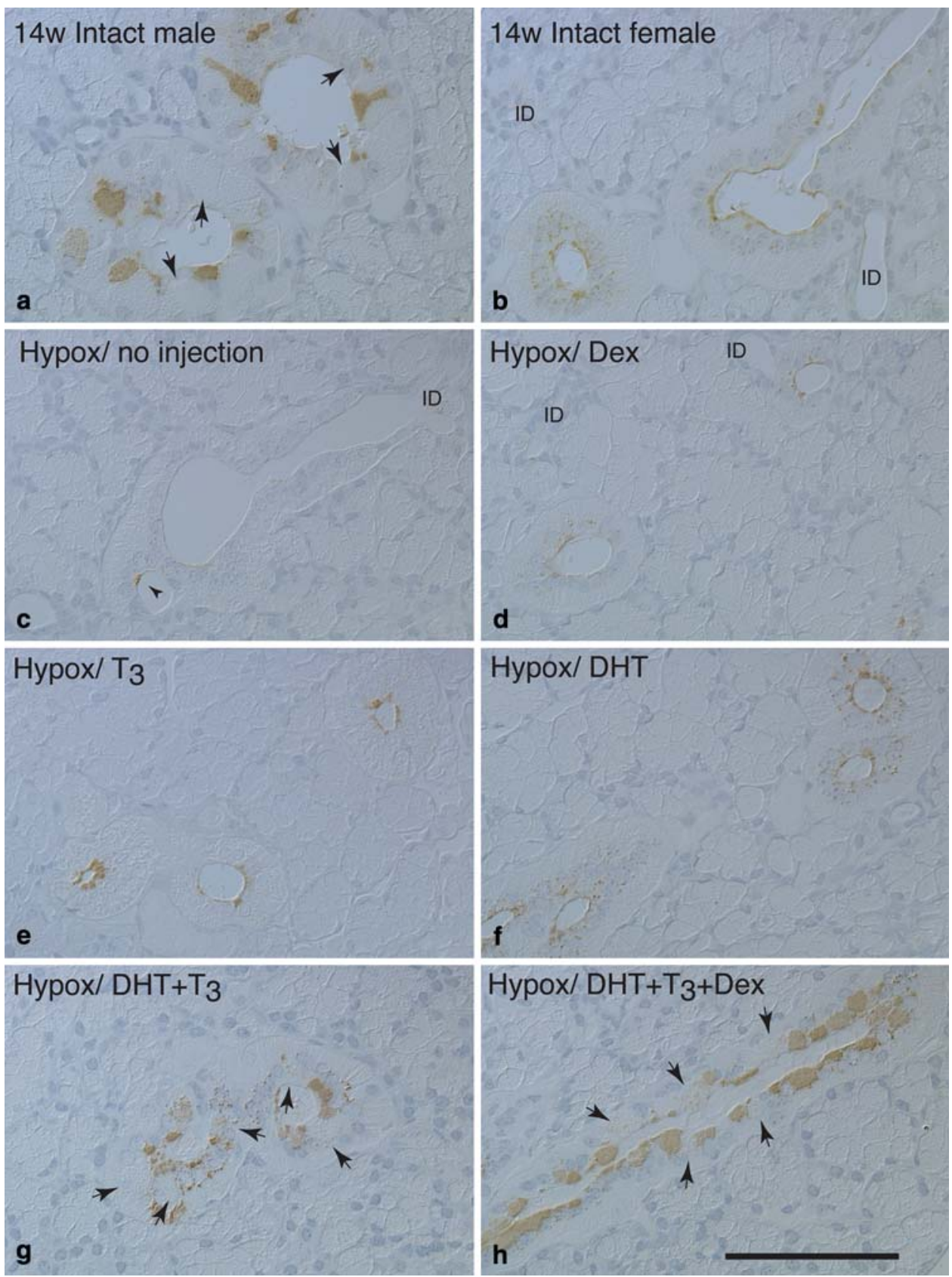

and full-fledged granular cells, in the intact male mice glands, and significantly higher than the percentage of granular duct cells in the glands of the control, untreated hypophysectomized male mice ( $P<0.0001$; Figs. 2, 3). Concomitant injection of $\mathrm{T}_{3}+$ Dex or DHT + Dex to the hypophysectomized male mice also had a trophic effect on the granular duct cells. However, the intensity/extent of mK1-immunostaining in these two groups (photographs not shown) was almost the same as that in the $\mathrm{T}_{3}$ alone group or DHT alone group. All the granular duct cells were composed of the transitional-type cells, showing positive staining for $\mathrm{mK} 1$, and the cells accounted for approximately $80 \%$ of the population of SD cells (Fig. 3). A significant trophic effect was also observed in the groups concomitantly injected with $\mathrm{DHT}+\mathrm{T}_{3}$, and with all the three hormones. The granular duct cells in these two groups accounted for approximately $80 \%$ of the population of the striated duct cells, being close to that in the intact male mice group and other hormoneinjected groups (Fig. 3). It was noteworthy that these hormone injections induced the appearance of many full-fledged cells in the granular duct segments, with some of them showing positive staining for $\mathrm{mK} 1$, and others showing negative staining (Fig. 1g, h), similar to the observation in the glands of the intact male mice (Fig. 1a). In these two 


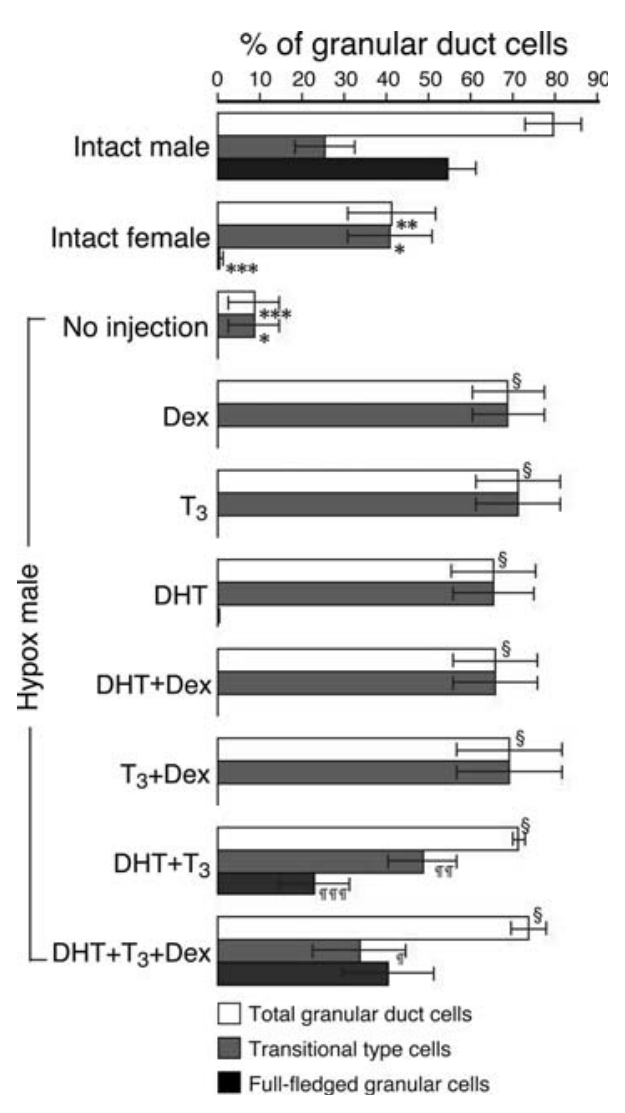

Fig. 2 Bar graphs showing the percentage of full-fledged granular cells, transitional cells, and total granular duct cells (composed of both types of granular cells) occupying the striated duct segments. All values are the mean $\pm \mathrm{sd}$ of five animals. $* P<0.005$, ** $P<0.001$, *** $P<0.0001$, significantly different from the intact male mice group. $\S P<0.0001$, significantly different from the untreated hypophysectomized male mice (No injection) group, and $P<0.01$, ๑ $P<0.001$, $\uparrow=0.0001$, significantly different from the intact male mice group

groups, the percentage of total granular duct cells was approximately the same as that in the intact male mice and the hypophysectomized hormone-injected mice groups. The percentage of transitional cells was significantly decreased (Fig. 2), with full-fledged granular cells appearing instead. In the DHT $+\mathrm{T}_{3}$ group, the percentage of full-fledged granular cells was over $20 \%$ of the population of granular duct cells, but did not reach the percentage of this type of cells observed in the intact male mice group $(P<0.0001$; Figs. 2,3). mK1 showed a mosaic cellular distribution in the full-fledged granular cells; approximately half of the cells showed positive staining for $\mathrm{mK} 1$, while the others showed negative staining for $\mathrm{mK} 1$ (Fig. 3). In the DHT $+\mathrm{T}_{3}+$ Dex group, the percentage of full-fledged granular cells was significantly increased by over $40 \%$ (Fig. 2). However, the percentage of the full-fledged cells showing positive staining for $\mathrm{mK} 1$ was still lower in the group injected with three hormones than in the intact male mice group $(P<0.005$; Fig. 3).



Fig. 3 Bar graph showing the percentage of full-fledged granular cells positively stained or negatively stained for $\mathrm{mK} 1$, occupying the striated duct segments. All values are the mean \pm sd of five animals. $* P<0.05$; ** $P<0.005$; *** $P<0.0005$, significantly different from the intact male mice group

Electron-microscopic immunocytochemistry

The results of ultrastructural analysis by immunogold staining confirmed the findings of light microscopy. In the glands of the hypophysectomized male mice, a significant decrease in the number of cells of the granular phenotype in the majority of striated duct segments. In the distal portions, connecting to intercalated ducts (Fig. 4), the duct



Fig. 4 Electron micrograph of cells of the distal striated duct near to the intercalated duct in the gland of a hypophysectomized male mice; immunostaining with anti-mK1 antiserum. No secretory granules are seen in any cells of this duct segment. L, Lumen; M, mitochondria; $N$, nucleus. Bar $=2 \mu \mathrm{m}$ 
cells lacked secretory granules, and had round nuclei in their apical one-third to one-half (Fig. 4). Numerous membrane infoldings associated with elongated mitochondria were developed at their base. The Golgi apparatus was poorly defined, and fragments of rough endoplasmic reticulum (RER) were sparse in their electron-lucent cytoplasm. In the groups injected with DHT alone, $\mathrm{T}_{3}$ alone, or Dex alone, reappearance of mK1-immunoreactive transitional-type cells was observed in the glands of the hypophysectomized male mice under the light microscope, as described above. Although secretory granules could not be detected in these mK1-positive cells by light microscopy, electron microscopy revealed electron-dense secretory granules, which were very small and a few in number, and were condensed in their subluminal cytoplasm. The presence of gold particles, indicating the presence of $\mathrm{mK} 1$, was restricted to these secretory granules (Fig. 6). There were, however, variations in the size and density of these secretory granules among the hormoneinjected groups. The secretory granules were the smallest and fewest in number in the Dex alone group (Fig. 5), while they were a little larger and greater in number in the
Fig. 5 Electron micrograph of an apical area of granular duct cells in the gland of hypophysectomized male mouse injected with Dex or DHT (inset); immunostaining with anti-mK1 antiserum. Almost secretory granules are labeled with gold particles, indicating the presence of $\mathrm{mK} 1$. $\mathrm{L}$, lumen; $\mathrm{N}$, nucleus.

Bar $=2 \mu \mathrm{m}$
Fig. 6 Electron micrograph of a cross section of a granular duct segment, composed of fullfledged granular cells and transitional cells, in the gland of a hypophysectomized male mouse injected with DHT $+\mathrm{T}_{3}$; immunostaining with anti-mK1 antiserum. Immunogold labeling for $\mathrm{mK} 1$ is seen on the secretory granules of some fullfledged granular cells and transitional cells, which are marked by asterisks. L, Lumen. Bar $=4 \mu \mathrm{m}$. Inset: Enlarged view of the border between two mK1-positive and -negative full-fledged granular cells (boxed) showing gold labeling for $\mathrm{mK} 1$ on the secretory granules of the cell marked by asterisk. Bar $=1 \mu \mathrm{m}$

groups given DHT alone or $\mathrm{T}_{3}$ alone. The Golgi apparatuses and RER were not well developed. Except for the presence of these secretory granules, ultrastructurally, the transitional cells closely resembled the non-granulated striated duct cells. The full-fledged granular cells in the glands of the hypophysectomized male mice groups injected with DHT $+\mathrm{T}_{3}$ or all of the three hormones packed an abundant number of large electron-dense secretory granules in the apical two-thirds of their cytoplasm and a round nucleus at the base. Stacked cisternae of RER and large Golgi apparatuses with swollen cisternae were seen in the perinuclear region. Short membrane infoldings associated with mitochondria were always observed in the narrow space between the nucleus and the basal membrane (data not shown; see Kurabuchi and Gresik 2001). As shown in Fig. 6, some full-fledged granular cells whose secretory granules were strongly labeled by gold particles, and others whose secretory granules were negatively labeled with gold particles were seen in the same duct segments, showing mosaic cellular distribution of $\mathrm{mK} 1$. There were no ultrastructural differences between the mK1-positive and mK1-negative fullfledged granular cells. On the other hand, all the transitional cells scattered between the full-fledged granular cells showed positive staining for $\mathrm{mK} 1$, and many of the cells showed labeling of the secretory granules by gold particles (Fig. 6). As compared with the transitional cells in the mice groups injected with DHT alone or Dex alone (Fig. 5), the secretory granules were more abundant and somewhat larger in the mice groups injected with $\mathrm{DHT}+\mathrm{T}_{3}$ or DHT + Dex (Fig. 6).

\section{Discussion}

The results of this immunocytochemical study in the SLG SDs of ICR-strain mice indicated that full-fledged granular cells showed a mosaic cellular distribution of $\mathrm{mK} 1$ : some cells were mK1-positive, while others were mK1-negative, and almost all the transitional cells showed positive immunostaining for $\mathrm{mK} 1$. Considering that secretory granules are much larger and more abundant in the former type of cells than in the latter, the mK1 level per cell might be remarkably higher in a mK1-positive full-fledged granular cell than in a mK1-positive transitional cell. Furthermore, in the glands of male mice, these two cell types were mixed in the SDs, whereas nearly all the granular duct cells were transitional-type in the glands of female mice. Taken together, our findings suggested that, even though a large population of full-fledged granular cells was devoid of $\mathrm{mK} 1$ synthesis in male mice, the total $\mathrm{mK} 1$ output of this gland may be higher than that in female mice; this conclusion also agrees with the results of a previous biochemical study (Murai 1987).

Hypophysectomy resulted in a significant decrease in granular duct cells in the SLGs of male mice in this study. All residual granular cells, containing only a few small secretory granules, were positively stained for $\mathrm{mK} 1$. Likewise, the hypophysectomy caused a significant atrophy in the SMG GCT cells (Hosoi et al. 1992), and nearly all of them were stained positive for $\mathrm{mK} 1$ (Kurabuchi et al. 2004). Furthermore, we previously suggested that many SD cells of mouse parotid gland possess a few small secretory granules that are mK1-positive and that hypophysectomy resulted in complete degranulation (Kurabuchi and Hosoi 2004). These findings suggest a close similarity between the SDs of the major three mouse salivary glands, in that they are both granulated and dependent upon pituitarydependent hormones.

The repeated injection of one of three hormones (DHT, $\mathrm{T}_{3}$, or Dex) to hypophysectomized mice resulted in the recovery of granulation in many SD cells, all of which were positively stained for $\mathrm{mK} 1$, though no full-fledged granular cells were induced. This result suggests that each of the hormones can induce the gene expression of $\mathrm{mK} 1$ in many granular duct cells. Stronger hormonal replacement therapy in the hypophysectomized mice, concomitantly injected with DHT and $\mathrm{T}_{3}$ with or without Dex, resulted in the induction of full-fledged granular cells. From these results, it may be surmised that the additive and/or synergistic actions of androgen and thyroid hormone may have converted some of the transitional cells to full-fledged granular cells, while other transitional cells, despite being exposed to the same blood levels of these hormones, retained their original form. In addition, some of the fullfledged granular cells, but not the transitional cells, were unable to synthesize $\mathrm{mK} 1$. Thus, $\mathrm{mK} 1$ is down regulated by androgen and thyroid hormone on the condition that the granular cell phenotype of the transitional cells developed into a full-fledged granular cell phenotype. However, for the reason mentioned at the beginning of this section, we assumed that the $\mathrm{mK} 1$ content in the gland would increase remarkably after the repeated injection of DHT, $\mathrm{T}_{3}$, and/or Dex. Therefore, biochemical analyses alone are not sufficient to arrive at a conclusion regarding the regulation of $\mathrm{mK} 1$, because the presence of $\mathrm{mK} 1$-negative granular cells, as detected using immunocytochemical analyses in this study, would be masked, as shown in previous biochemical studies (Murai 1987; Kurihara et al. 1999).

Mosaic cellular distribution of $\mathrm{mK} 1$ was also observed in the SMG GCTs in adulthood, even though the population of mK1-positive GCT cells was very small, and the mK1-positive and mK1-negative GCTs were not significantly different ultrastructurally (Kurabuchi et al. 1999). We suspect that the mK1-negative granular cells might 
have a slightly more differentiated granular cell phenotype. Only a few GCT cells with very small secretory granules have been reported to account for the minority of GCT cells in the SMG (Hazen-Martin et al. 1987; Matsuura et al. 1984; Mori et al. 1992). We have shown that these cells usually stain positive for mK1 (Kurabuchi et al. 1999). These minor cells in the SMG GCTs probably represent transitional cells. As described above, the SDs in the parotid glands of intact male and female mice consist of many granular duct cells with a poor granular cell phenotype, all of which immunostained positive for mK1 (Kurabuchi and Hosoi 2004). These findings suggest that the down-regulation of $\mathrm{mK} 1$ is limited to full-fledged granular cells.

We proposed in our previous report that variations in androgen receptor, thyroid hormone receptor and adrenocortical hormone receptor levels might divide the SMG GCT cells into various cell types, causing the mosaic cellular distribution of mK1 (Kurabuchi et al. 2004). In the present study, the cells might or might not have developed into full-fledged granular cells and may or may not have lost their ability to synthesize $\mathrm{mK} 1$, depending upon the expression levels of the androgen and thyroid hormone receptors. The expression level of the androgen receptor has been shown to vary among GCT cells (Morrel et al. 1987; Sawada and Noumura 1995). To the best of our knowledge, however, no studies have investigated hormone receptor expression in rodent SLGs. The actions of hormones might be similar in the duct systems of the mouse SMG, SLG and parotid glands. However, the hormoneresponsiveness of each granular duct cell type might differ, and it is well known that the cellular composition differs in the duct system of each of the three major salivary glands. Some particular type of granular duct cells, such as fullfledged granular cells, might be more abundant in SMGs than in SLGs. All of the SD cells in the parotid glands retain their original form into adulthood.

Finally, our previous and present studies suggest that $\mathrm{mK} 1$ expression is suppressed in granular duct cells with a granular cell phenotype that has been fully developed by androgen and thyroid hormone, in contrast to the usual stimulatory effect of this class of hormones on growth factors and renin, including other kallikreins. As previously described, mK9, mK13, and $\mathrm{mK} 22$ were known to act as processing enzymes upon growth factors and renin. Considering the unique distribution and regulation of $\mathrm{mK} 1$, this enzyme may have a unique function in mouse salivary glands. Indeed, an endocrine release of glandular kallikrein from the basolateral surface of granular duct cells in the mouse SMG has been suggested (Penschow and Coghlan 1993).

Open Access This article is distributed under the terms of the Creative Commons Attribution Noncommercial License which permits any noncommercial use, distribution, and reproduction in any medium, provided the original author(s) and source are credited.

\section{References}

Barka T (1980) Biologically active polypeptides in submandibular glands. J Histochem Cytochem 28:836-859

Berg T, Bradshaw RA, Carretero OA, Chao L, Clements JA, Fahnestock $M$ et al (1992) A common nomenclature for members of the tissue (glandular) kallikrein gene family. Agents Actions Suppl 38(Pt 1):19-25

Evans BA, Drinkwater CC, Richards RI (1987) Mouse glandular kallikrein genes. Structure and partial sequence analysis of the kallikrein gene locus. J Biol Chem 262:8027-8034

Ganong WF (1997) Cardiovascular regulatory mechanism in Review of Medical Physiology, 18th edn. Prentice-Hall International Inc, London, pp 553-566

Hazen-Martin DJ, Landreth G, Simson JAV (1987) Immunocytochemical localization of nerve growth factor in mouse salivary glands. Histochem J 19:210-216. doi:10.1007/BF01680631

Hosoi K, Tanaka T, Ishii Y, Ueha T (1983) A new esteroproteinase (proteinase F) from the submandibular glands of female mice. Biochim Biophys Acta 756:163-170

Hosoi K, Tanaka T, Murai T, Ueha T (1984) Inhibitory effect of androgen on the synthesis of proteinase $\mathrm{F}$ in the male mouse submandibular gland. J Endocr 100:253-262

Hosoi K, Maruyama S, Ueha T, Sato S, Gresik EW (1992) Additive and/or synergistic effects of 5- $\alpha$-dihydrotestosterone, dexamethasone, and triiod-L-thyronine on induction of proteinases and epidermal growth factor in the submandibular glands of hypophysectomized mice. Endocrinology 130:1044-1055. doi: 10.1210/en.130.2.1044

Hosoi K, Tsunasawa S, Kurihara K, Aoyama H, Ueha T, Murai T et al (1994) Identification of $\mathrm{mK} 1$, a true tissue (glandular) kallikrein of mouse submandibular gland: tissue distribution and a comparison of kinin-releasing activity with other submandibular kallikreins. J Biochem 115:137-143

Kim WS, Nakayama K, Nakayama T, Kawamura Y, Haraguchi K, Murakami K (1991) Mouse submandibular gland proreninconverting enzyme is a member of glandular kallikrein family. $\mathbf{J}$ Biol Chem 266:19283-19287

Kurabuchi S (2002) Morphologic changes in the granular convoluted tubule cells of the mouse submandibular gland following hypophysectomy and hormonal replacement. Odontology 90:27-34. doi:10.1007/s102660200004

Kurabuchi S (2006) Repeated androgen and thyroid hormone injection modulates the morphology of hormone-responsive duct cells in the mouse parotid gland. Odontology 94:29-37. doi: 10.1007/s10266-006-0064-2

Kurabuchi S, Gresik EW (2001) Ultrastructural study of hormonally responsive striated duct cells in the mouse sublingual gland. Odontology 89:34-40. doi:10.1007/s10266-001-8182-3

Kurabuchi S, Hosoi K (2004) Immunocytochemical localization of $\mathrm{mK} 1$, a true tissue kallikrein, in the mouse parotid gland: sexual dimorphism and effects of castration and hypophysectomy. Odontology 92:73-76. doi:10.1007/s10266-004-0040-7

Kurabuchi S, Tada J, Gresik EW, Hosoi K (1999) An unusual sexually dimorphic mosaic distribution of a subset of kallikreins in the granular convoluted tubule of the mouse submandibular gland detected by an antibody with restricted immunoreactivity. Histochem J 31:19-28. doi:10.1023/A:1003506302065

Kurabuchi S, Hosoi K, Gresik EW (2001) Androgen regulation of the cellular distribution of the true tissue kallikrein $\mathrm{mK} 1$ in the 
submandibular gland of the mouse. J Histochem Cytochem 49:801-802

Kurabuchi S, Hosoi K, Gresik EW (2002) Developmental and androgenic regulation of the immunocytochemical distribution of $\mathrm{mK} 1$, a true tissue kallikrein, in the granular convoluted tubule of the mouse submandibular gland. J Histochem Cytochem 50:135-146

Kurabuchi S, Hosoi K, Gresik EW (2004) Additive and/or synergistic action (down regulation) of androgens and thyroid hormones on the cellular distribution and localization of a true tissue kallikrein, $\mathrm{mK} 1$, in the mouse submandibular gland. J Histochem Cytochem 52:1437-1446. doi:10.1369/jhc.4A6333.2004

Kurihara K, Maruyama S, Nakanishi N, Sakagami H, Ueha T (1999) Thyroid hormone (3,5,3'-triiodo-L-thyronine) masking/inversion of stimulatory effect of androgen on expression of mk1, a true tissue kallikrein, in the mouse submandibular gland. Endocrinology 140:3003-3011. doi:10.1210/en.140.7.3003

Mason AJ, Evans BA, Cox DR, Shine J, Richards RI (1983) Structure of mouse kallikrein gene family suggests a role in specific processing of biologically active peptides. Nature 303:300-307. doi:10.1038/303300a0

Matsuura S, Sahara N, Suzuki K (1984) Fine structure of submandibular glands of mice with testicular feminization $(\mathrm{Tfm} / \mathrm{Y})$. Cell Tissue Res 235:295-301. doi:10.1007/BF00217853

Mori M, Takai Y, Kunikata M (1992) Review: biologically active peptides in the submandibular gland-role of the granular convoluted tubule. Acta Histochem Cytochem 25:325-341
Morrel J, Gresik EW, Barka T (1987) Autoradiographic localization of dihydrotestosterone binding in the major salivary glands and other responsive organs of the mouse. J Histochem Cytochem 35:1053-1058

Murai T (1987) Studies on proteinase F in major salivary glands of inbred mice-Sex difference of proteinase $\mathrm{F}^{-}$. Jpn J Oral Biol 29:416-427 in Japanese

Penschow JD, Coghlan JP (1993) Secretion of glandular kallikrein and renin from the basolateral pole of mouse submandibular duct cells: an immunocytochemical study. J Histochem Cytochem 41:95-103

Satch RW, Server AC, Pignatti PF, Piltch A, Shooter EM (1976) Characterization of the $\mathrm{g}$ subunits of the $7 \mathrm{~S}$ nerve growth factor complex. Biochemistry 15:1455-1461. doi:10.1021/bi00652a016

Satch RW, Pignatti PF, Barker ME, Shooter EM (1980) The characterization of the subunits of $7 \mathrm{~S}$ nerve growth factor. J Neurochem 34:850-8585. doi:10.1111/j.1471-4159.1980.tb09657.x

Sawada K, Noumura T (1995) Developmental pattern of androgen receptor immunoreactivity in the mouse submandibular gland. Zool Sci 12:243-248

Smith AP, Varon S, Shooter EM (1968) Multiple forms of the nerve growth factr protein and its subunits. Biochemistry 7:3259-3268. doi: $10.1021 / \mathrm{bi00849a032}$

Taylor JM, Mitchell WM, Cohen S (1974) Characterization of the binding protein for epidermal growth factor. J Biol Chem 249:2188-2194 